\title{
Performance Evaluations of the Abbott Alinity m Assay in Comparison with the Abbott m2000 Assay for Hepatitis B and Hepatitis C Viruses
}

\author{
Jaeeun Yoo ${ }^{1,2}$, Beom Se Son ${ }^{1}$, Eunhee Han ${ }^{1,2}$, Gyong Gi Yu${ }^{1}$, and Seungok Lee ${ }^{1,2}$ \\ ${ }_{1}^{1}$ Department of Laboratory Medicine, Incheon St. Mary's Hospital, College of Medicine, The Catholic University of Korea, Incheon; \\ 2Department of Laboratory Medicine, College of Medicine, The Catholic University of Korea, Seoul, Korea
}

\section{Corresponding author:}

Seungok Lee

Department of Laboratory Medicine, Incheon St. Mary's Hospital, College of Medicine, The Catholic University of Korea, 56 Dongsu-ro, Bupyeong-gu, Incheon 21431, Korea

Tel +82-32-280-5512

Fax +82-32-280-5520

E-mail lsok@catholic.ac.kr

Received: April 24, 2020

Revised: July 10, 2020

Accepted: July 14, 2020
This is an Open Access article distributed under the terms of the Creative Commons Attribution Non-Commercial License (http://creativecommons.org/licenses/ by-nc/4.0) which permits unrestricted non-commercial use, distribution, and reproduction in any medium, provided the original work is properly cited.
Background: The quantification of the hepatitis B virus (HBV) or hepatitis $C$ virus (HCV) is critical for the diagnosis and prognostic follow-up of the viral infection. The Alinity $m$ assay is a recently developed, fully automated "random-access" system for quantitative molecular assays. The aim of this study was to verify the validity of the Alinity $m$ assay by comparing its performance in HBV and HCV quantifications with the established Abbott m2000 HBV and HCV assays.

Methods: The precision, linearity, limit of detection (LOD), correlation with the Abbott $\mathrm{m} 2000$ assay, and interference were evaluated.

Results: The within-laboratory standard deviation ranged from 0.106 to $0.137 \log \mathrm{IU} / \mathrm{mL}$ for HBV and from 0.073 to $0.097 \log \mathrm{IU} / \mathrm{mL}$ for HCV, which was lower than the manufacturer's specification of $0.25 \mathrm{log} \mathrm{IU} / \mathrm{mL}$, indicating good precision. Linearity was observed from 1.14 to $8.14 \mathrm{log} \mathrm{IU} / \mathrm{mL}$ for the HBV assay and from 1.09 to $7.09 \log \mathrm{IU} / \mathrm{mL}$ for the HCV assay. The LODs of $\mathrm{HBV}$ and $\mathrm{HCV}$ were 10 and $6.39 \mathrm{IU} / \mathrm{mL}$, respectively, which were equivalent to or better than those claimed by the manufacturer. For comparative evaluation between Alinity $\mathrm{m}$ and $\mathrm{m} 2000$ assays, $142 \mathrm{HBV}$ and $70 \mathrm{HCV}$ samples were tested. The correlation test revealed a strong correlation for both markers, and the Passing-Bablok regression analysis did not reveal any significant deviation.

Conclusions: The Alinity $\mathrm{m}$ assay demonstrated excellent performance for HBV and HCV quantifications with reduced hands-on time and a randomaccess format.

(Lab Med Qual Assur 2020;42:150-155)

Key Words Hepatitis B virus, Hepatitis C virus, DNA, RNA, Quantification test

\section{INTRODUCTION}

The diagnoses of hepatitis B virus (HBV) and hepatitis $C$ virus (HCV) infections rely on viral nucleic acid testing (NAT) [1]. The quantifications of HBV DNA and HCV RNA are critical for the diagnosis, establishing the prognosis of the viral infection, and monitoring the virologic response to anti-viral therapy [2]. International clinical practice guidelines recommend the use of sensitive NAT for HBV DNA and HCV RNA detections.

Many automated molecular quantification systems have been developed and are in use in laboratories. However, most molecular systems operate generally on a batch testing of multiple samples, resulting in little flexibility, 
delayed results, and increased costs. The Alinity $m$ (Abbott Molecular Inc., Des Plaines, IL, USA) is a recently developed fully automated "random-access" system for quantitative molecular assays. It provides the first result of less than 115 minutes and a throughput of up to 300 samples in 8 hours. The Alinity $m$ system allows samples to be assayed as soon as they arrive in the laboratory, throughout the day, reducing the turnaround time and hands-on time of medical technicians.

Here, we evaluated the analytical performance of Alinity $\mathrm{m} \mathrm{HBV}$ and $\mathrm{HCV}$ quantification assays with the established Abbott m2000 HBV and HCV assays (Abbott Molecular Inc.). The study protocol was approved by the Institutional Review Board of the Catholic University of Korea (OC19DISI0178).

\section{MATERIALS AND METHODS}

Ethylenediamine tetraacetic acid blood samples received for viral quantification were tested between December 2019 and January 2020. Blood samples were centrifuged, and aliquots of plasma were stored at $-80^{\circ} \mathrm{C}$ for several days. Each aliquot was thawed out once and centrifuged before processing on the Alinity m or m2000 assay. Assays were calibrated to international standards. The precision, linearity, lower limit of detection (LOD), correlation, and interference were evaluated. Comparisons were conducted for 142 clinical samples of HBV and 70 clinical samples of HCV. MedCalc ver. 19.0 (MedCalc, Ostend, Belgium) was used for the statistical analysis, and $P<0.05$ was considered statistically significant.

To assess the precision, a set of commercial controls and calibrator consisting of three different levels $(2,4$, and $6 \log \mathrm{IU} / \mathrm{mL}$ ) of HBV (Abbott RealTime HBV Control, Abbott Molecular Inc.; Abbott RealTime HBV Calibrator, Abbott Molecular Inc.) and HCV (Abbott RealTime HCV Control, Abbott Molecular Inc.; Abbott RealTime HCV Calibrator, Abbott Molecular Inc.) were assayed in duplicate, twice a day for 5 consecutive days according to the Clinical and Laboratory Standards Institute (CLSI) guidelines [3]. Package inserts specify that Alinity $\mathrm{m} \mathrm{HBV}$ and HCV were designed to achieve a within-laboratory standard deviation (SD) of less than or equal to $0.25 \log \mathrm{IU} / \mathrm{mL}$.

The linearities of the Alinity $\mathrm{m} \mathrm{HBV}$ and HCV were verified in the claimed linear range for each DNA and RNA level according to CLSI guidelines [4]. The claimed measuring interval ranged from 1.0 to $9.0 \log \mathrm{IU} / \mathrm{mL}$ for the HBV assay and from 1.0 to $8.0 \log \mathrm{IU} / \mathrm{mL}$ for the $\mathrm{HCV}$ assay. Ten serially diluted pooled plasma samples ranging from 1.14 to $8.14 \log \mathrm{IU} / \mathrm{mL}$ were measured in duplicate for HBV, and seven serially diluted plasma samples ranging from 1.09 to $7.09 \log \mathrm{IU} / \mathrm{mL}$ were measured for HCV. The linear fit, second order, and third order polynomial regression analyses were performed. The regression equation was obtained ( $y$, measured concentration; $x$, expected concentration) using a linear-fit model.

LODs of HBV and HCV were evaluated using samples including levels of LOD claimed by the manufacturer according to CLSI guidelines [5]. The LOD in the HBV assay was estimated by testing 15 replicates of two levels of the Abbott m2000 HBV-positive control (10 and $20 \mathrm{IU} /$ $\mathrm{mL}$ ). For the LOD of HCV, the positive control was diluted to approximately 6,9 , and $12 \mathrm{IU} / \mathrm{mL}$ and tested 14 times for $6 \mathrm{IU} / \mathrm{mL}$ while 12 times for 9 and $12 \mathrm{IU} / \mathrm{mL}$. The probit analysis was used for the HCV LOD estimation.

For correlation evaluation between Alinity $m$ and m2000 assays, $142 \mathrm{HBV}$ and $70 \mathrm{HCV}$ samples ranging from 0 to $8.71 \log \mathrm{IU} / \mathrm{mL}$ for HBV and from 0 to $6.95 \log$ $\mathrm{IU} / \mathrm{mL}$ for HCV (determined using the m2000 assay) were sequentially chosen at random. Method comparisons were evaluated with the Passing-Bablok regression with quantifiable results (HBV: 105/142; HCV: 28/70) according to CLSI guidelines [6].

Common potentially interfering factors, hemoglobin, triglycerides, and bilirubin were studied by adding these substances to ten HBV-positive, ten HCV-positive, and three negative samples, respectively. Test results were compared before and after the addition of the substances.

\section{RESULTS}

\section{Precision}

Table 1 shows the within-run and within-laboratory 
SDs of HBV and HCV tests. Both HBV and HCV had within-laboratory SDs lower than the manufacturer's specification $(0.25 \log \mathrm{IU} / \mathrm{mL})$. The results suggest a good precision at all clinically meaningful levels.

\section{Linearity}

Linearity was observed from 2.14 to $8.14 \log \mathrm{IU} / \mathrm{mL}$ in HBV and from 2.09 to $7.09 \mathrm{log} \mathrm{IU} / \mathrm{mL}$ in HCV (Fig. 1). The regression equation was obtained ( $y$, measured concentration; $x$, expected concentration) using a linear-fit model: $y=0.9897+0.8223 x, r=0.995$ (recovery rate, $96 \%-$ $187 \%$ ) for HBV, and $\mathrm{y}=-0.6187+1.081 \mathrm{x}, r=0.998$ (recovery rate, $49 \%-100 \%)$ for HCV. The expected bias for nonlinearity between the linear fit and the best non-linear (second order polynomial) fit in HBV was $21.4 \%$ (95\% confidence interval $[\mathrm{Cl}], 13.6 \%$ to $29.1 \%), 1.6 \%$ (95\% Cl,
$1.0 \%$ to $2.2 \%),-3.3 \%(95 \% \mathrm{Cl},-4.5 \%$ to $-2.1 \%),-4.2 \%$ (95\% Cl, $-5.7 \%$ to $-2.7 \%),-3.4 \%$ (95\% Cl, -4.6 to $-2.2 \%$ ), $-1.7 \%(95 \% \mathrm{Cl},-2.3$ to $-1.1 \%), 0.5 \%(95 \% \mathrm{Cl}, 0.3$ to $0.7 \%)$, and $3.0 \%(95 \% \mathrm{Cl}, 1.9 \%$ to $4.1 \%)$ at $1.14,2.14,3.14,4.14$, $5.14,6.14,7.14$, and $8.14 \log \mathrm{IU} / \mathrm{mL}$, respectively. No second- or third-order polynomial fit is statistically better than a linear fit at the $5 \%$ significance level in HCV.

\section{Limit of detection verification}

All $30 \mathrm{HBV}$ samples (10 and $20 \mathrm{IU} / \mathrm{mL}$ ) were detected by Alinity $m$ HBV. The claimed LOD of HBV by the manufacturer was $10 \mathrm{IU} / \mathrm{mL}$, equivalent to our result. The Alinity $\mathrm{m} \mathrm{HCV}$ assay detected all the $12-$ and $9-\mathrm{IU} / \mathrm{mL}$ samples but missed two $6-I U / \mathrm{mL}$ samples. The LOD of $\mathrm{HCV}$ was calculated as $6.39 \mathrm{IU} / \mathrm{mL}$ by the probit analysis. The result was better than the claimed LOD $(12 \mathrm{IU} / \mathrm{mL})$

Table 1. Precision results of the Alinity $m$ HBV and HCV assays

\begin{tabular}{|c|c|c|c|c|c|c|}
\hline \multirow{2}{*}{ Variable } & \multicolumn{3}{|c|}{ HBV } & \multicolumn{3}{|c|}{$\mathrm{HCV}$} \\
\hline & High* $^{*}$ & Medium & Low & High & Medium & Low \\
\hline Within-run SD & 0.074 & 0.116 & 0.125 & 0.089 & 0.054 & 0.076 \\
\hline Within-run CV (\%) & 1.2 & 2.6 & 5.2 & 1.5 & 1.1 & 2.8 \\
\hline Within-lab SD & 0.106 & 0.137 & 0.126 & 0.097 & 0.073 & 0.076 \\
\hline Within-lab CV (\%) & 1.6 & 3.1 & 5.2 & 1.6 & 1.5 & 2.8 \\
\hline
\end{tabular}

Abbreviations: HBV, hepatitis B virus; HCV, hepatitis C virus; $\mathrm{SD}$, standard deviation; CV, coefficient of variation.

${ }^{*} \mathrm{High,} 6 \log \mathrm{IU} / \mathrm{mL}$; medium, $4 \log \mathrm{IU} / \mathrm{mL}$; low, $2 \log \mathrm{IU} / \mathrm{mL}$.

A

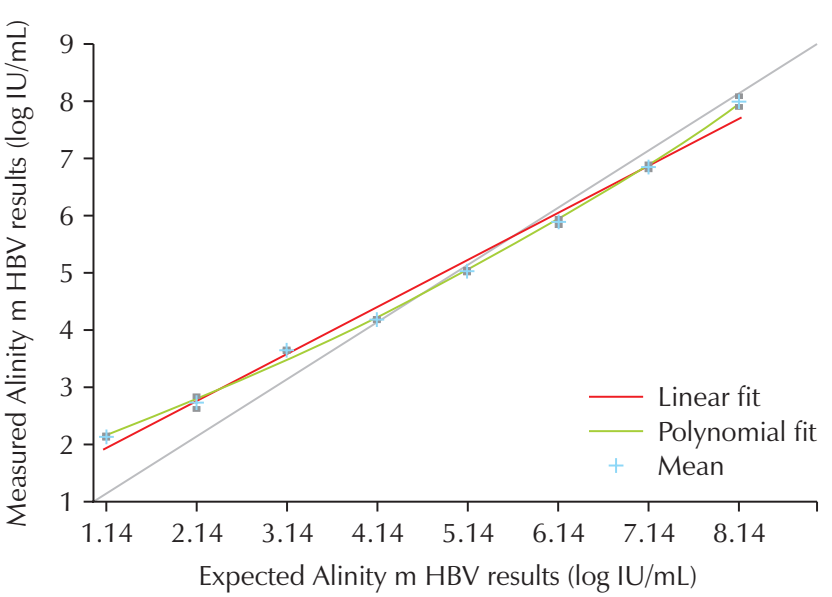

B

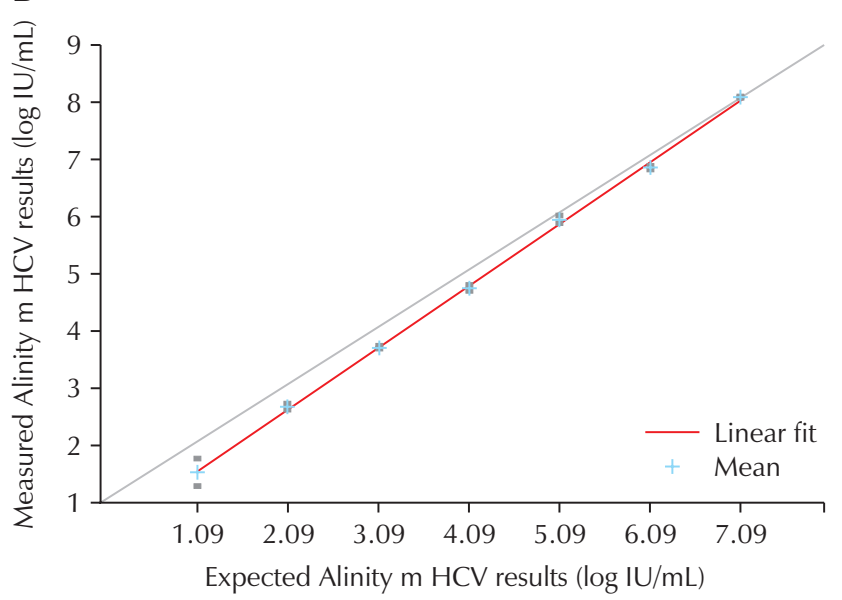

Fig. 1. Linearity graph of Alinity $m \mathrm{HBV}(\mathrm{A})$ and HCV (B) assays. Abbreviations: HBV, hepatitis B virus; HCV, hepatitis C virus. 
Table 2. Quantitative concordance of viral load results by the Alinity $\mathrm{m}$ and $\mathrm{m} 2000$ assays

\begin{tabular}{|c|c|c|c|c|c|c|}
\hline \multirow{3}{*}{ Abbott Alinity m } & \multicolumn{6}{|c|}{ Abbott m2000 } \\
\hline & \multicolumn{3}{|c|}{ HBV } & \multicolumn{3}{|c|}{$\mathrm{HCV}$} \\
\hline & Quantified & $\begin{array}{l}\text { Detected } \\
\quad<\text { LOD }\end{array}$ & Not detected & Quantified & $\begin{array}{l}\text { Detected } \\
<\text { LOD }\end{array}$ & Not detected \\
\hline Quantified & 105 & 0 & 0 & 28 & 1 & 1 \\
\hline Detected $<$ LOD & 2 & 6 & 4 & 1 & 4 & 1 \\
\hline Not detected & 0 & 2 & 23 & 0 & 1 & 33 \\
\hline
\end{tabular}

HBV concordance: 94.4\% (134/142); HCV concordance: $92.9 \%$ (65/70).

Abbreviations: HBV, hepatitis B virus; HCV, hepatitis C virus; LOD, limit of detection.

A

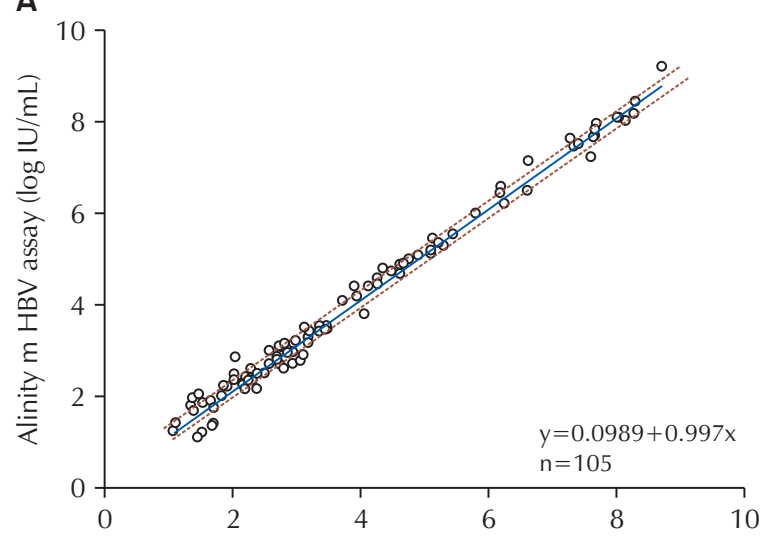

HBV DNA level in Abbott m2000 HBV assay $(\log \mathrm{IU} / \mathrm{mL})$

\section{C}

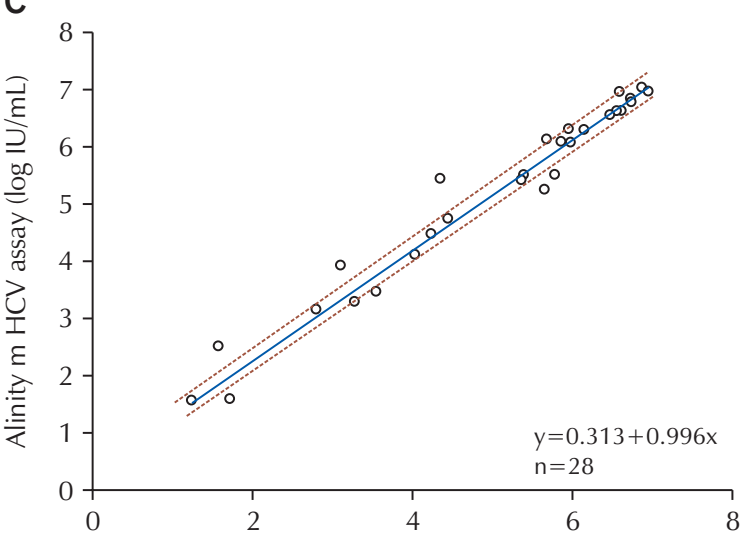

HCV RNA level in Abbott m2000 HCV assay $(\log \mathrm{IU} / \mathrm{mL})$
B

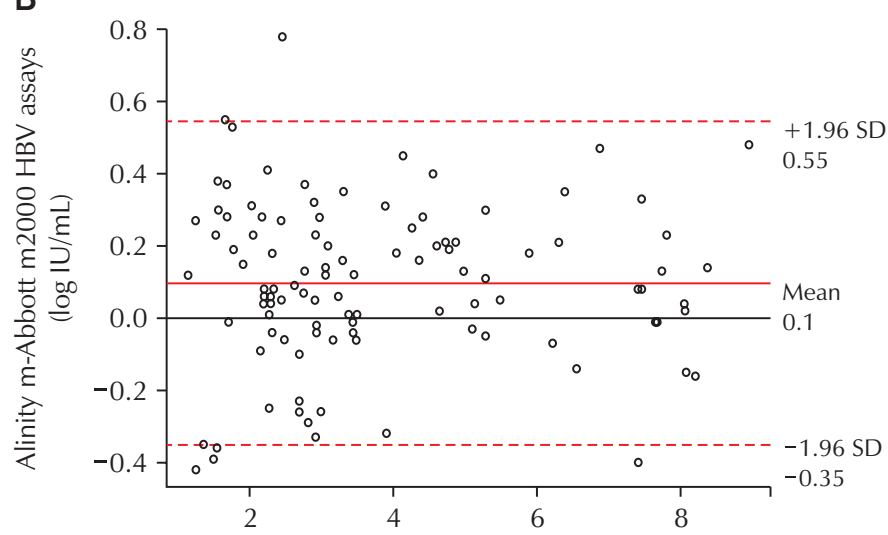

Mean of HBV DNA level in Alinity $m$ HBV and Abbott m2000 HBV assays (log IU/mL)

D

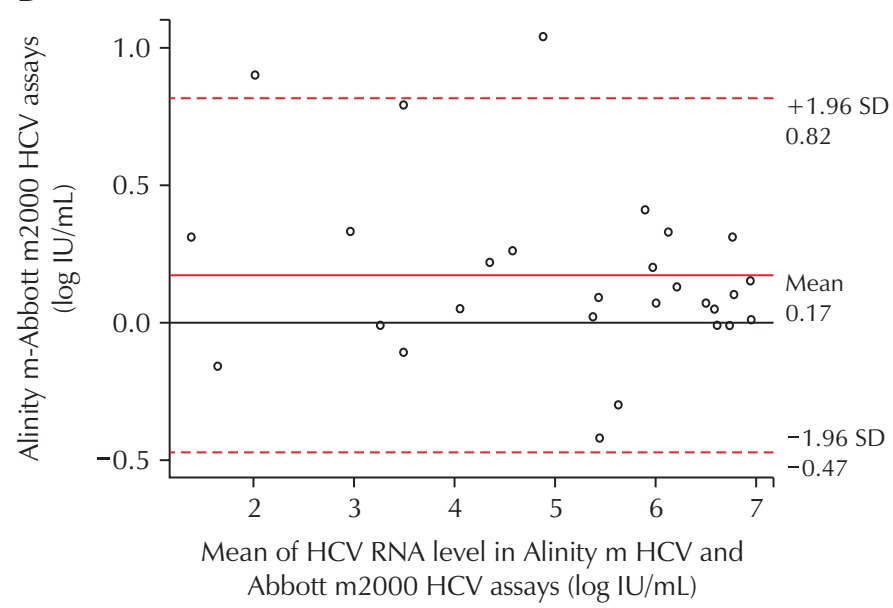

Fig. 2. Quantitative agreement between Alinity m HBV, HCV, and m2000 assays. (A) The Passing-Bablok analysis for HBV results, with correlation coefficient $r$ of 0.986. (B) Difference plot (Bland-Altman analysis) for HBV results showing a mean difference of 0.1 log IU/ $\mathrm{mL}$ between assays. (C) The Passing-Bablok analysis for HCV results, with correlation coefficient $r$ of 0.980 . (D) Difference plot (BlandAltman analysis) for HCV results showing a mean difference of $0.17 \log \mathrm{lU} / \mathrm{mL}$ between assays. Abbreviations: HBV, hepatitis B virus; HCV, hepatitis $\mathrm{C}$ virus. 
according to the manufacturer.

\section{Correlation}

Among the $142 \mathrm{HBV}$ samples, 105 showed quantified results both in Alinity $\mathrm{m}$ and $\mathrm{m} 2000$ (Table 2). For HCV, among 70 samples, 28 showed quantified results. Two samples showed "not detected" in Alinity m HBV that turned detected $(<10 \mathrm{IU} / \mathrm{mL}$ ) in the $\mathrm{m} 2000$ assay, whereas four samples showed the opposite pattern. Among 70 HCV samples, two were detected (261 and $<12 \mathrm{IU} / \mathrm{mL}$, respectively) in the Alinity $\mathrm{m} \mathrm{HCV}$ assay and turned "not detected" in the m2000 assay, and one "not detected" in Alinity $\mathrm{m} \mathrm{HCV}$ turned detected $(<12 \mathrm{IU} / \mathrm{mL})$ in the $\mathrm{m} 2000$ assay. The overall concordance between the Alinity $\mathrm{m}$ and m2000 analyses was $94.4 \%$ (134/142) for HBV and 95.7\% (67/70) for HCV.

The correlation test with quantified tests showed a strong correlation for both markers (Fig. 2). The PassingBablok regression analysis did not reveal any significant deviation from linearity between the two assays, and 97.14\% of HBV samples (102/105) and $92.86 \%$ of HCV samples (26/28) showed delta differences less than $0.5 \mathrm{log}$ $\mathrm{IU} / \mathrm{mL}$. The mean difference in viral DNA levels between the two assays was $0.1 \log \mathrm{IU} / \mathrm{mL}$ for HBV and $0.17 \log \mathrm{IU} /$ $\mathrm{mL}$ for $\mathrm{HCV}$.

\section{Interference}

Hemoglobin, triglycerides, or bilirubin showed no interferences with the HBV test results.

\section{DISCUSSION}

The clinical performances of the novel Alinity $m$ assays for HBV and HCV quantifications were compared to those of m2000 assays. We showed that the Alinity m assay has an excellent precision and analytic sensitivity, with an estimated LOD equivalent to that claimed by the manufacturer. Quantitative HBV and HCV results showed a strong correlation and estimated to be equivalent within allowable differences with $\mathrm{m} 2000$ assays.

Alinity $\mathrm{m}$ systematically showed higher concentrations for both HBV and HCV compared to m2000 (0.08 log IU/
$\mathrm{mL}$ for HBV and $0.10 \log \mathrm{IU} / \mathrm{mL}$ for HCV), consistent with another comparison study [7]. The target sequences and LODs for HBV and HCV remained unchanged in both assays, but a second probe was added. The overquantification might have resulted from the improved performance in Alinity $\mathrm{m}$, and since it avoids falsenegative results, it is not a disadvantage.

Qualitative discrepancies were observed both in HBV (8/142, 5.6\%) and HCV (5/70, $7.1 \%)$ tests (Table 2). All discrepancies were observed in the low tittered samples, and the lower precision in NAT assays at low viremic levels could lead to such qualitative discrepancies. In HBV, Alinity $\mathrm{m}$ detected four samples that were not detected in the m2000 assay, and other two samples showed the opposite pattern. The HCV assays showed a similar tendency. Alinity m HCV detected two samples that were negative in the m2000 assay, and only one sample showed the opposite pattern. It suggests that Alinity $\mathrm{m}$ is more sensitive compared to $\mathrm{m} 2000$, and Bland-Altman graphs show the same results (Fig. 2). The mean of Alinity m-m2000 was $+0.1 \log \mathrm{IU} / \mathrm{mL}$ for HBV and $+0.17 \log$ IU/ $\mathrm{mL}$ for HCV. The more sensitive performance of Alilnity $\mathrm{m}$ could support its use in clinical practice more precisely.

The analytical turnaround time and hands-on time are significantly decreased in the Alinity $\mathrm{m}$ assay. Ready-touse reagents, random access, and 30 minutes of handson time of the Alinity $m$ assay improved the laboratory workflow and technicians' availability dramatically. Without the need to work in a batch mode, Alinity $\mathrm{m}$ provides the results on a daily basis, and it helps physicians to decide patients' management in time.

A limitation of our study is that different HBV genotypes were not tested on HBV DNA quantification. Most HBV genotypes in Korea are genotype $\mathrm{C} 2$ or a mixed pattern of genotypes $B$ and $C$, and other genotypes rarely occur $[8,9]$. Although only minor differences were observed among genotypes A, B, C, D, and E in a study [10], in the study of Braun et al. [11], the genotype affected in quantification showed higher results than expected for genotype $D$ and lower results than expected for genotype $A$.

In conclusion, the Alinity $\mathrm{m}$ assays demonstrated a performance similar to the m2000 assay for HBV and 
HCV quantifications. With a reduced hands-on time and random-access format, it is suitable for high-throughput HBV DNA and HCV RNA monitoring in large hospital laboratories.

\section{ACKNOWLEDGMENTS}

All reagents for the study were supplied by Dow Biomedica Inc. We thank Abbott Inc. for the excellent technical assistance.

\section{REFERENCES}

1. Schweitzer A, Horn J, Mikolajczyk RT, Krause G, Ott JJ. Estimations of worldwide prevalence of chronic hepatitis B virus infection: a systematic review of data published between 1965 and 2013. Lancet 2015;386:1546-55.

2. European Association for the Study of the Liver. EASL 2017 Clinical Practice Guidelines on the management of hepatitis B virus infection. J Hepatol 2017;67:370-98.

3. Tholen DW, Kallner A, Kennedy JW, Krouwer JS, Meier K. Evaluation of precision performance of quantitative measurement methods; approved guideline: EP5-A2. 2nd ed. Wayne (PA): Clinical and Laboratory Standards Institute, 2004.

4. Tholen DW, Kroll M, Astles JR, Caffo AL, Happe TM, Krouwer J, et al. Evaluation of the linearity of quantitative measurement procedures: a statistical approach; approved guideline. Wayne (PA): Clinical and Laboratory Standards Institute, 2003.

5. Pierson-Perry JF, Vaks JE, Durham AP, Fischer C, Gutenbrunner C, Hillyard D, et al. Evaluation of detection capability for clinical laboratory measurement procedures; approved guideline. 2nd ed. Wayne (PA): Clinical and Laboratory Standards Institute, 2012.

6. Krouwer JS, Tholen DW, Garber CC, Goldschmidt HM, Kroll MH, Linnet K, et al. Method comparison and bias estimation using patient samples; approved guideline: EP9-A2. 2nd ed. Wayne (PA): Clinical and Laboratory Standards Institute, 2002.

7. Mouna L, Pallier C, Proust S, Pregermain C, Roque-Afonso AM. Comparison of the Abbott Alinity $m$ and $\mathrm{m} 2000$ assays for the quantification of HIV-1, HCV and HBV in clinical samples. J Clin Virol 2020;126:104331.

8. Cho JH, Yoon KH, Lee KE, Park DS, Lee YJ, Moon HB, et al. Distribution of hepatitis B virus genotypes in Korea. Korean J Hepatol 2009;15:140-7.

9. Park J, Cho H, Choi SJ, Lee GD, Sin SH, Ryu JH, et al. Performance evaluation of the Beckman Coulter DxN VERIS hepatitis B virus (HBV) assay in comparison with the Abbott RealTime HBV assay. Ann Lab Med 2019;39:86-90.

10. Schonning K, Johansen K, Nielsen LG, Weis N, Westh H. Analytical performance of the Hologic Aptima HBV Quant Assay and the COBAS Ampliprep/COBAS TaqMan HBV test v2.0 for the quantification of HBV DNA in plasma samples. J Clin Virol 2018;104:83-8.

11. Braun P, Delgado R, Drago M, Fanti D, Fleury H, Izopet J, et al. A European multicientre study on the comparison of HBV viral loads between VERIS HBV assay and Roche COBAS(R) TAQMAN(R) HBV test, Abbott RealTime HBV assay, Siemens VERSANT HBV assay, and Qiagen artus HBV RG kit. J Clin Virol 2017;95:76-83. 